\title{
A novel esterase from a soil metagenomic library displaying a broad substrate range
}

\author{
Jian Yao ${ }^{*}$, Lun Gui and Shaocheng Yin
}

\begin{abstract}
A novel esterase gene was isolated from a soil metagenomic library. The gene encoded a protein of 520 amino acids which contained a 21 aa signal peptide. Primary structure analysis of the protein sequence revealed that it contained a conserved active site motif ( $\mathrm{S} \times \mathrm{S} \times \mathrm{G}$ ) and a structural motif (CS-D-HC). Then the esterase gene was cloned and expressed in Escherichia coli BL21(DE3). SDS-PAGE analysis of the purified esterase showed that it was expressed in a highly soluble form and its molecular mass was estimated to be $55 \mathrm{kDa}$. Characterization of the esterase revealed that it exhibited high activity toward $p$-nitrophenyl esters with short acyl chains and especially $p$-nitrophenyl acetate, suggesting that it was a typical carboxylesterase rather than a lipase. With $p$-nitrophenyl acetate as substrate, the enzyme showed its optimal activity at $\mathrm{pH} 7.0$ and $30^{\circ} \mathrm{C}$, and it was stable at a broad $\mathrm{pH}$ range from 4.5 to 10.0 and temperature not higher than $50^{\circ} \mathrm{C}$. Furthermore, the enzyme showed different substrate specificity from known esterase, it was not only hydrolyzing against $p$-nitrophenyl esters, but also hydrolyzing all hydroxybenzoic esters and hydroxycinnamic ester assayed. As it was an enzyme active on a broad range of phenolic esters, simultaneously possessing feruloyl esterase, chlorogenate esterase and tannase activities, it could serve as a valuable candidate for applications in biotechnology.
\end{abstract}

Keywords: Multi-functional esterase, Tannase, Chlorogenate esterase, Feruloyl esterase

\section{Introduction}

Plant cell wall polysaccharides, the major reservoir of fixed carbon in nature, had been divided into three main groups: cellulose, hemicellulose and lignin (Kosugi et al. 2001). In addition to these main groups, phenolic compounds were thought to be playing a key role in structure of the plant cell wall as they covalently cross-linked plant cell wall polysaccharides to each other by ester bonds (Ishii 1997; Nieter et al. 2015). Furthermore, phenolic compounds were also reported to protect plants from oxidative stress, UV radiation, invasion and infection (Jaleel et al. 2009). Thus, these phenolic compounds not only influenced the rigidity and mechanical properties of the cell wall but also played a role in plant defense (Nieter et al. 2015; Cosgrove 2001). Phenolic compounds showed a large diversity of structures, from simple

*Correspondence: yaojian417@163.com

Institute of Agricultural Applied Microbiology, Jiangxi Academy of Agricultural Sciences, Nanchang 330200, People's Republic of China molecules e.g. phenolic acids to polymeric compounds based on these different classes (Cheynier 2012). Hydroxycinnamic acids (such as caffeic, ferulic, $p$-coumaric and chlorogenic acids) and hydroxybenzoic acids (such as tannins), two classes of typical phenolic acids, were derived from benzoic and cinnamic acids, respectively (Koseki et al. 2010). With the in-depth study, the industrial use of phenolic acids had attracted growing interest because of their potential biological properties, such as antioxidant, chelating, free radical scavenging and antiinflammatory (Rice-Evans et al. 1996; Natella et al. 1999; Silva et al. 2000; Castelluccio et al. 1996). Therefore, the removal of these phenolic compounds and the breakdown of ester linkages between polymers allowed numerous exploitations for pharmaceuticals industrial and food applications.

Lipolytic enzymes, including esterases and lipases, belonged to the general class of carboxylic ester hydrolases (EC 3.1.1) that catalyzed both the hydrolysis and formation of ester bonds. While esterases (carboxylic
Springer Open (c) The Author(s) 2021. This article is licensed under a Creative Commons Attribution 4.0 International License, which permits use, sharing, adaptation, distribution and reproduction in any medium or format, as long as you give appropriate credit to the original author(s) and the source, provide a link to the Creative Commons licence, and indicate if changes were made. The images or other third party material in this article are included in the article's Creative Commons licence, unless indicated otherwise in a credit line to the material. If material is not included in the article's Creative Commons licence and your intended use is not permitted by statutory regulation or exceeds the permitted use, you will need to obtain permission directly from the copyright holder. To view a copy of this licence, visit http://creativeco mmons.org/licenses/by/4.0/. 
acid esterases, EC 3.1.1.1) hydrolyzed water-soluble or emulsified esters with short chain carboxylic acids with less than 10 carbons, lipases (EC 3.1.1.3) preferred longchain fatty acids with more than 10 carbons (Gao et al. 2016). Feruloyl esterases (FAEs, E.C. 3.1.1.73), represented a subclass of the carboxylic acid esterases, could enable and facilitate the access of hydrolases to the backbone wall polymers. With synergy of xylanases, cellulases and pectinases, feruloyl esterases had been used as a key enzyme to break down complex plant cell wall carbohydrates (Crepin et al. 2003; Faulds and Williamson 1995; Kroon and Williamson 1996). Other carboxylic acid esterases, tannase (E.C. 3.1.1.20) catalyzed the hydrolysis of ester and depsidic linkage in hydrolysable tannins releasing gallic acid and glucose, while chlorogenate esterase (E.C. 3.1.1.42) catalyzed the hydrolysis of the ester bond presented in chlorogenic acid (Ramírez et al. 2008). Up to date, these types of carboxyl ester hydrolases from different organisms had been isolated, characterized and some of them were industrially produced. However, the use of carboxyl ester hydrolases with new specificities was still needed (Tutuncu et al. 2019). In the view of high demand for these biocatalysts in biotechnology, new experimental approaches had been developed over last few years, such as metagenomic which was a cultivation-independent method recovering directly total DNA of culturable and uncultured microorganisms from environmental samples for discovering novel enzymes with unique bioactivities.

In this study, a novel esterase (Tan410) gene was isolated from a soil metagenomic library by function-driven screening approach. The esterase gene was cloned, expressed in E.coli BL21(DE3) and purified for investigating biochemical characteristics of the recombinant enzyme. From the esterase assayed, Tan 410 was not only able to hydrolyze phenolic ester, but also able to hydrolyze hydroxycinnamic and hydroxybenzoic ester, indicating that a novel esterase with a novel function was isolated from a soil metagenomic library.

\section{Materials and methods}

All chemicals (phenyl acetate, ethyl acetate, propyl acetate, butyl acetate, isobutyl acetate, ethyl butyrate, ethyl hexanoate, ethyl octanoate, ethyl decanoate, ethyl oleate, vinyl acetate, vinyl butyrate, vinyl decanoate, vinyl pivalate, isopropenyl acetate, glyceryl triacetate, glyceryl tributyrate, methyl bromoacetate, ethyl bromoacetate, methyl glycolate, ethyl gallate, propyl gallate, methyl benzoate, ethyl benzoate, vinyl benzoate, methyl 4-hydroxybenzoate, ethyl 4-hydroxybenzoate, methyl vanillate, methyl 2,4-dihydroxybenzoate, methyl 2,5-dihydroxybenzoate, methyl 3,4-dihydroxybenzoate, methyl 3,5-dihydroxybenzoate, methyl ferulate, methyl caffeate, methyl p-coumarate, methyl sinapinate, chlorogenic acid, caffeic acid, ferulic acid, gallic acid, cinnamic acid, vanillic acid, benzoic acid, sinapic acid, 4-hydroxybenzoic, 2,4-dihydroxybenzoic acid, 3,4-dihydroxybenzoic acid, 2,5-dihydroxybenzoic acid and 3,5-dihydroxybenzoic acid) were purchased from Aladdin (Shanghai China) and SigmaAldrich (Taufkirchen, Germany) unless otherwise noted.

\section{Metagenomic library construction, esterase gene screening and sequence analysis}

Metagenomic DNA extraction from soil and metagenomic library construction was based on the method described previously (Yao et al. 2011). 5-bromo-4-chloro3 -indolyl- $\beta$-D-indolyl caprylate was used as selection substrate for esterase gene screening. Clones with blue transparent circles around was chosen for reconfirmed and sub-cloned. DNA sequencing was carried out by using an ABI Prism 377 DNA sequencer (Applied Biosystems, Inc.) and sequence analysis was performed by online server Open Reading Frame (ORF) Finder (.nih. gov/orffinder/) (Hancock and Bishop 2004). Amino acid sequence alignment of homologous esterases was carried out by Clustal W program (Larkin et al. 2007). Protein functional domains of esterase were analyzed by comparing its sequence with those in the NCBI and Pfam databases. Molecular weight and $\mathrm{p} I$ of the protein was predicted by ProtParam tool as implemented in ExPASy (Gasteiger et al. 2005).

\section{Expression and purification of recombinant esterase}

Gene encoding Tan 410 was amplified using primers $\mathrm{f} 1$ (5'-CGCGGATCCATGCCCGCAAAAACCCGCCTG$\left.3^{\prime}\right)$ and w1 (5'-CCCAAGCTTATTCCCGTTAGTAAA GCCGTC-3') (restriction sites underlined for BamHI and HindIII, respectively). PCR products were purified and cloned into restriction digested pET-28a $(+)$ and transformed into E.coli BL21(DE3). Positive clone was grown in a $500-\mathrm{mL}$ flask containing $300 \mathrm{~mL} \mathrm{LB}$ at $37{ }^{\circ} \mathrm{C}$ until the cell concentration reached an $\mathrm{OD}_{600}$ of 0.8 , and then were induced with $0.4 \mathrm{mM}$ IPTG at $25{ }^{\circ} \mathrm{C}(12 \mathrm{~h}$, $180 \mathrm{rpm})$. Culture cells were harvested by centrifugation $(12,000 \times g, 5 \mathrm{~min})$ and resuspended with $30 \mathrm{~mL}$ lysis buffer $\left(50 \mathrm{mM} \mathrm{NaH}_{2} \mathrm{PO}_{4}, 300 \mathrm{mM} \mathrm{NaCl}, 5 \mathrm{mM}\right.$ imidazole, $\mathrm{pH}$ 8.0). Then cells were sonicated and supernatant was collected by centrifugation at $4{ }^{\circ} \mathrm{C}(16,000 \times g, 15$ $\mathrm{min}$ ). Subsequently, the supernatant incubated with $5 \mathrm{~mL}$ $\mathrm{Ni}-\mathrm{NTA}$ resin in a closed column for $1 \mathrm{~h}$ on a rocking shaker at $4{ }^{\circ} \mathrm{C}$. Purification was performed according to the manufacturer's instructions. The column was washed two times with $30 \mathrm{~mL}$ wash buffer I $\left(50 \mathrm{mM} \mathrm{NaH}_{2} \mathrm{PO}_{4}\right.$, $300 \mathrm{mM} \mathrm{NaCl}, 10 \mathrm{mM}$ imidazole, $\mathrm{pH}$ 8.0), followed by 30 $\mathrm{mL}$ wash buffer II $\left(50 \mathrm{mM} \mathrm{NaH}_{2} \mathrm{PO}_{4}, 300 \mathrm{mM} \mathrm{NaCl}, 20\right.$ $\mathrm{mM}$ imidazole, $\mathrm{pH}$ 8.0). Target protein was eluted with 
$5 \mathrm{~mL}$ elution buffer $\left(50 \mathrm{mM} \mathrm{NaH} \mathrm{PO}_{4}, 300 \mathrm{mM} \mathrm{NaCl}\right.$, $250 \mathrm{mM}$ imidazole, $\mathrm{pH} 8.0$ ), and elution fractions were rebuffered with $50 \mathrm{mM}$ phosphate buffer ( $\mathrm{pH}$ 7.0). The purification was monitored using denaturing SDS-PAGE analysis (12\% separating gel and 5\% concentrating gel) according to Laemmli (Laemmli 1970).

\section{Spectrophotometric assays of substrate specificity and esterase activity}

Substrate specificity of purified Tan 410 was determined in $50 \mathrm{mM}$ phosphate buffer (pH 7.0) containing $1 \mathrm{mM}$ of $p$-nitrophenyl esters such as $p$-nitrophenyl acetate (C2), $p$-nitrophenyl butyrate (C4), $p$-nitrophenyl caproate $(\mathrm{C} 6)$, $p$-nitrophenyl caprylate (C8), $p$-nitrophenyl decanoate (C10) under standard conditions $\left(30^{\circ} \mathrm{C}\right.$ for $\left.5 \mathrm{~min}\right)$. Stock substrate solutions $(30 \mathrm{mM})$ were prepared by dissolving $p$ NP-esters in pure methanol.

Esterase activity was performed with $p$ NP-esters as substrates. Reactions containing $0.1 \mathrm{~mL}$ of enzyme solution and $0.1 \mathrm{~mL}$ of $5 \mathrm{mM}$ substrate in $50 \mathrm{mM}$ Tris- $\mathrm{HCl}$ $\left(\mathrm{pH}\right.$ 7.0) were incubated at $30^{\circ} \mathrm{C}$ for $5 \mathrm{~min}$. Production of $p$-nitrophenol was measured at $410 \mathrm{~nm}$. One unit (U) of esterase activity was defined as the amount of enzyme that released $1 \mu \mathrm{mol}$ of $p$-nitrophenol per minute.

Substrate profile of purified Tan 410 was determined by using an ester library (phenyl acetate, ethyl acetate, propyl acetate, butyl acetate, isobutyl acetate, ethyl butyrate, ethyl hexanoate, ethyl octanoate, ethyl decanoate, ethyl oleate, vinyl acetate, vinyl butyrate, vinyl decanoate, vinyl pivalate, isopropenyl acetate, glyceryl triacetate, glyceryl tributyrate, methyl bromoacetate, ethyl bromoacetate and methyl glycolate) with $p$-nitrophenol used as a $\mathrm{pH}$ indicator to monitor ester hydrolysis colorimetrically (Esteban-Torres et al. 2013). Blank reactions with $1 \mathrm{mM}$ sodium phosphate buffer ( $\mathrm{pH}$ 7.0) were carried out for each substrate.

Esterase activity on gallate esters (tannase activity) was determined using a rhodamine assay specific for gallic acid (Inoue and Hagerman 1988). And the amount of gallic acid in reaction mixture was determined as described previously (Yao et al. 2011). One unit of tannase activity was defined as the amount of enzyme required to release $1 \mu \mathrm{mol}$ of gallic acid per minute.

\section{Effect of temperature and $\mathrm{pH}$ on esterase activity}

The optimum temperature for esterase activity of Tan 410 was assayed by incubating the enzyme in $50 \mathrm{mM}$ phosphate buffer ( $\mathrm{pH} 7.0)$ at different temperatures in a range of $25-65{ }^{\circ} \mathrm{C}$. Thermostability of Tan 410 was investigated by pre-incubating the enzyme at $25-65^{\circ} \mathrm{C}$ for $1 \mathrm{~h}$ and then analyzing the residual activity. The optimal $\mathrm{pH}$ values of Tan 410 was measuring its activity at different $\mathrm{pH}$ values (4.0-9.0). Following buffers were used for the assay: $50 \mathrm{mM}$ sodium acetate buffer $(\mathrm{pH} 4.0-6.0)$; $50 \mathrm{mM}$ phosphate buffer ( $\mathrm{pH} 5.5-8.0) ; 50 \mathrm{mM}$ Tris- $\mathrm{HCl}$ buffer ( $\mathrm{pH}$ 7.5-9.0). To study $\mathrm{pH}$ stability, Tan410 was incubated in different buffers ( $\mathrm{pH} 4.0-12.0)$ for $1 \mathrm{~h}$. Then the pre-incubated solution was regulated to $\mathrm{pH} 7.0$ with $500 \mathrm{mM}$ phosphate buffer and analyzed for the residual activity.

\section{Effect of metal ions, detergents, inhibitor and organic solvents on esterase activity}

Effects of metal ions $\mathrm{Mg}^{2+}, \mathrm{Mn}^{2+}, \mathrm{Cu}^{2+}, \mathrm{Co}^{2+}, \mathrm{Zn}^{2+}$, $\mathrm{K}^{+}, \mathrm{Fe}^{2+}, \mathrm{Ni}^{2+}, \mathrm{Ca}^{2+}, \mathrm{Ag}^{+}$and $\mathrm{Pb}^{2+}$ ), detergents [CTAB (Cetyltrimethylammonium bromide) and SDS (Sodium dodecyl sulfate)] and inhibitor phenylmethylsulfonyl fluoride (PMSF) on esterase activity were investigated. Reaction solutions were assayed by incubating Tan 410 and various metal ions $(5 \mathrm{mM})$ for $1 \mathrm{~h}\left(\right.$ at $4{ }^{\circ} \mathrm{C}$ ) in 50 $\mathrm{mM}$ phosphate buffer ( $\mathrm{pH}$ 7.0) and then analyzing the residual activity. To estimate the organic solvent tolerance of Tan410, enzyme solutions were mixed with various organic solvents $(N, N$ - dimethyl formamide, ethyl acetate, isopropyl alcohol, isobutyl alcohol, isoamyl alcohol, acetone, methanol and ethanol) at a final concentration of $10 \%$, and incubated at $4{ }^{\circ} \mathrm{C}$ for $1 \mathrm{~h}$. Then the residual activity was assayed. Esterase activity measured in absence of any additive was taken as a control and was given a value of $100 \%$. The experiments were done in triplicate.

\section{HPLC analysis of Tan410 activity on phenolic esters}

Activity of Tan 410 against 17 potential substrates was analyzed by HPLC (high-performance liquid chromatography). Substrates assayed were esters derived from benzoic and hydroxycinnamic acids. Among benzoic acids, benzoic esters (methyl benzoate, ethyl benzoate and vinyl benzoate), hydroxybenzoic esters (methyl 4-hydroxybenzoate and ethyl 4-hydroxybenzoate), vanillic ester (methyl vanillate), dihydroxybenzoic esters (methyl 2,4-dihydroxybenzoate, methyl 2,5-dihydroxybenzoate, methyl 3,4-dihydroxybenzoate and methyl 3,5-dihydroxybenzoate) and gallic esters (ethyl gallate and propyl gallate) were analyzed. In relation to hydroxycinnamic acids, ferulic ester (methyl ferulate), caffeic ester (methyl caffeate), $p$-coumaric ester (methyl $p$-coumarate), sinapic ester (methyl sinapinate) and chlorogenic acid were analyzed. Enzyme solutions mixed with substrates $(1 \mathrm{mM})$ were incubated at $30^{\circ} \mathrm{C}$ for $30 \mathrm{~min}$. As controls, phosphate buffer containing reagents but not the enzyme was incubated under the same condition. Reactions were terminated by adding acetonitrile and formic acid and then analyzed by HPLC-UV method. Samples of reaction were centrifuged $(16,000 g \times 20 \mathrm{~min})$ before injection into HPLC column. Aliquots $(5 \mu \mathrm{L})$ of the reaction mixture 
were loaded onto the HPLC system (Agilent 1260 Infinity II, USA) using a $150 \times 3.0 \mathrm{~mm}$ Proshell 120 column (Agilent, USA). Substrates and products were separated by using a stepwise gradient at a flow velocity of $1.0 \mathrm{~mL}$ $\mathrm{min}^{-1}$ as follow: 10 to $30 \%$ acetonitrile in $10 \mathrm{~min}$. 30 to $56 \%$ acetonitrile in $1.5 \mathrm{~min}, 56$ to $96 \%$ acetonitrile in 0.5 min, 96 to $99 \%$ acetonitrile in $2.5 \mathrm{~min}, 99$ to $15 \%$ acetonitrile in $0.5 \mathrm{~min}, 15$ to $10 \%$ acetonitrile in $1 \mathrm{~min}$, and reequilibration with $10 \%$ acetonitrile for $1 \mathrm{~min}$, for a total run time of $17 \mathrm{~min}$. Substance elution was detected at $232 \mathrm{~nm}$ (benzoic, 2,4-dihydroxybenzoic acid, 2,5-dihydroxybenzoic acid, 3,4-dihydroxybenzoic acid and 3,5-dihydroxybenzoic acid), $254 \mathrm{~nm}$ (4-hydroxybenzoic and vanillic acids), $275 \mathrm{~nm}$ (cinnamic and gallic acids), $306 \mathrm{~nm}$ ( $p$-coumaric acid), and $323 \mathrm{~nm}$ (ferulic, caffeic, chlorogenic and sinapic acids).

\section{Nucleotide sequence accession number}

The nucleotide sequence reported in this study had been submitted to GenBank under the accession number HQ147564.

\section{Results}

\section{Esterase screening and sequence analysis}

A metagenomic library containing $9.2 \times 10^{4}$ clones with insert DNA sizes ranging from $2.5 \mathrm{~kb}$ to $5.0 \mathrm{~kb}$ was constructed for discovering esterase genes. Functional screening of the metagenomic library based on hydrolysis of 5-bromo-4-chloro-3-indolyl- $\beta$-D-indolyl caprylate resulted in the detection of a positive clone, forming a clear zone (bule color) on indicator plate. Sequence analysis revealed that the insert DNA fragment was $5335 \mathrm{bp}$ and harbored 21 possible functional ORFs as revealed by ORF Finder program, in which one ORF consisting of $1563 \mathrm{bp}$ was identified as a putative esterase named Tan410. Molecular weight and theoretical $\mathrm{p} I$ of the enzyme was predicated to be $54.88 \mathrm{kDa}$ and 4.66 , respectively. Analysis of the sequence using SignalP 5.0 predicted the first 21 amino acids of the protein served as a signal peptide (Sec/SPI), suggesting that Tan410 was naturally a secreted enzyme. It was also found that Tan 410 belonged to Pfam07519 family of the alpha/beta-hydrolases with a catalytic triad (serine, glutamate or aspartate, and histidine). Alignment of Tan410 with homologous sequences revealed that an active site motif Ser-X-Ser-XGly and a structural motif CS-D-HC in Tan410 sequence. (see Additional file 1: Figure S1).

\section{Expression and purification of recombinant esterase Tan410}

Gene $\tan 410$ was ligated to vector pET-28a $(+)$ and expressed in E .coli BL21 (DE3) for biochemical properties characterization. SDS-PAGE analysis of the purified enzyme showed a single band corresponding to about $55 \mathrm{kDa}$ which was in accordance with the theoretical molecular mass (see Additional file 2: Figure S2).

\section{Biochemical properties of esterase Tan410}

An ester library was used for testing substrate range of Tan410. And the highest hydrolytic activity was observed on vinyl butyrate, followed by ethyl hexanoate, phenyl acetate, isopropenyl acetate, ethyl octanoate and vinyl acetate. Tan410 also hydrolyzed other ester substrates, although showed less efficiency (such as ethyl butyrate, glyceryl triacetate, ethyl bromoacetate, methyl bromoacetate, glyceryl tributyrate, vinyl pivalate, isobutyl Acetate, ethyl acetate, propyl acetate and vinyl decanoate). However, Tan410 was unable to hydrolyze ethyl decanoate, ethyl oleate and methyl glycolate (Fig. 1). Esterase activity on purified Tan 410 was confirmed using $p$-nitrophenyl esters possessing different acyl chain lengths from $\mathrm{C}_{2}$ to $\mathrm{C}_{10}$. Tan410 was active on all substrates assayed, exhibiting a clear preference for $p$-nitrophenyl acetate which was selected as substrate for determining biochemical properties of Tan410 (Fig. 2). The optimum activity of esterase Tan410 was measured over a $\mathrm{pH}$ range of 5.5-8.0 and temperature range of $25-65{ }^{\circ} \mathrm{C}$. As shown in Fig. 3, esterase Tan 410 showed its highest activity at $\mathrm{pH} 7.0$, and more than $95 \%$ of initial activity remained after $1 \mathrm{~h}$ preincubation in $\mathrm{pH}$ range of 4.5-10.0 (Fig. 4). The optimum temperature of esterase Tan 410 was found to be $30^{\circ} \mathrm{C}$ and the enzyme still possessed more than $90 \%$ residual activity not higher than $55^{\circ} \mathrm{C}$ (Fig. 5). Thermostability of the enzyme was measured after pre-incubation at a temperature range of $35-65^{\circ} \mathrm{C}$. As shown in Fig. 6, it exhibited high thermostability and no activity was lost after heat treatment of temperature not higher than $50{ }^{\circ} \mathrm{C}$. However, when the temperature increased, the enzyme activity decreased; it remained about $83 \%, 54 \%$ and $37 \%$ of initial activity after pre-incubation at $55{ }^{\circ} \mathrm{C}, 60{ }^{\circ} \mathrm{C}$ and $65^{\circ} \mathrm{C}$, respectively.

Effect of various chemicals on Tan 410 activity was examined by pre-incubating the enzyme with chemicals in $50 \mathrm{mM}$ phosphate buffer $(\mathrm{pH} 7.0)$ for $1 \mathrm{~h}\left(\right.$ at $\left.4{ }^{\circ} \mathrm{C}\right)$ and then measuring its residual activity using $p$-nitrophenyl acetate as substrate. Results (Table 1) showed that all test metal ions $\mathrm{Mg}^{2+}, \mathrm{Mn}^{2+}, \mathrm{Cu}^{2+}, \mathrm{Co}^{2+}, \mathrm{Zn}^{2+}, \mathrm{K}^{+}, \mathrm{Fe}^{2+}$, $\mathrm{Ni}^{2+}, \mathrm{Ca}^{2+}, \mathrm{Ag}^{+}$and $\left.\mathrm{Pb}^{2+}\right)$ demonstrated inhibition on the enzyme activity. $\mathrm{Ag}^{+}$displayed more serious inhibition, remained only $4.5 \%$ of total activity. No activity was detected when SDS was added to the test solution. $\mathrm{N}, \mathrm{N}$ - dimethyl formamide and ethanol slightly increased esterase Tan 410 activity and methanol showed no affection on the enzyme activity. Esterase activity was slightly affected by ethyl acetate, isopropyl alcohol and acetone while highly inhibited by isoamyl alcohol. 


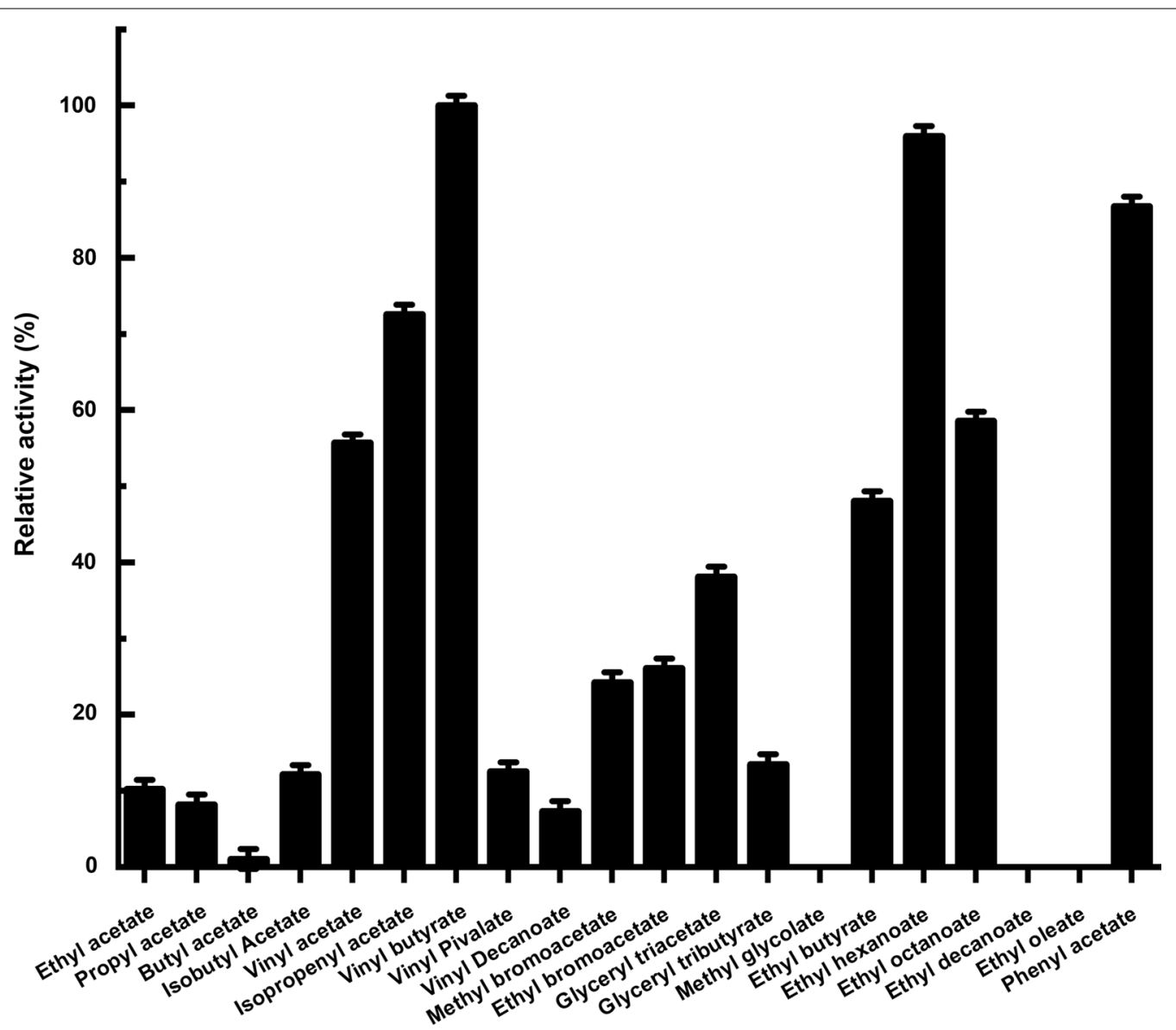

Fig. 1 Substrate profile of esterase Tan410

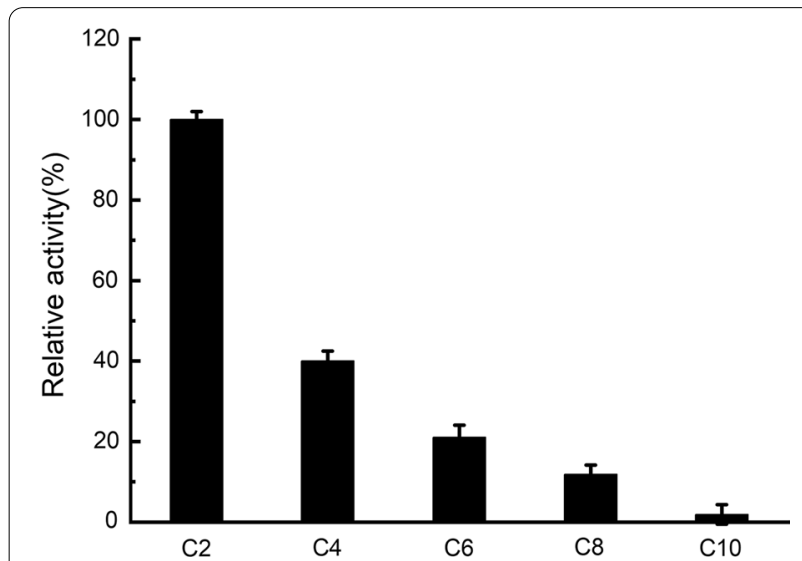

Fig. 2 Substrate specificity of esterase Tan410 toward p-nitrophenyl esters

Analysis of Tan410 on different substrates

A comprehensive set of substrates was examined for hydrolysis by esterase Tan410. As shown in Fig. 7, the

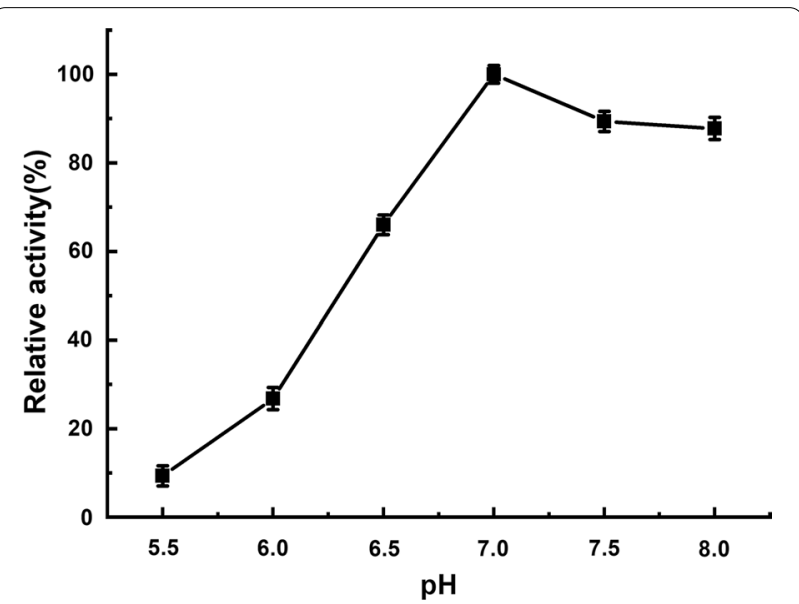

Fig. 3 Effect of $\mathrm{pH}$ on activity of esterase Tan410

determined specific activity for methyl ferulate was set to $100 \%$ and used for the calculation of relative activities for all other substrates. All tested substrates (ethyl 


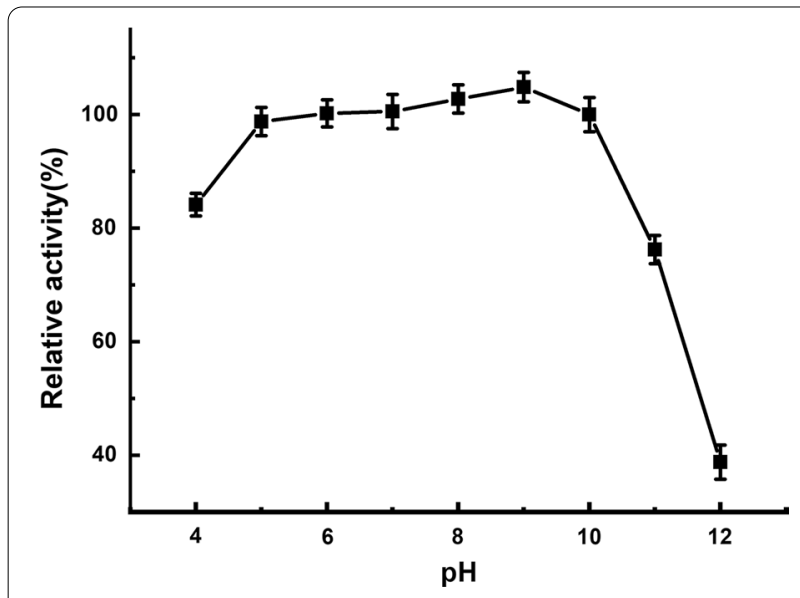

Fig. 4 Effect of pH on the stability of esterase Tan410

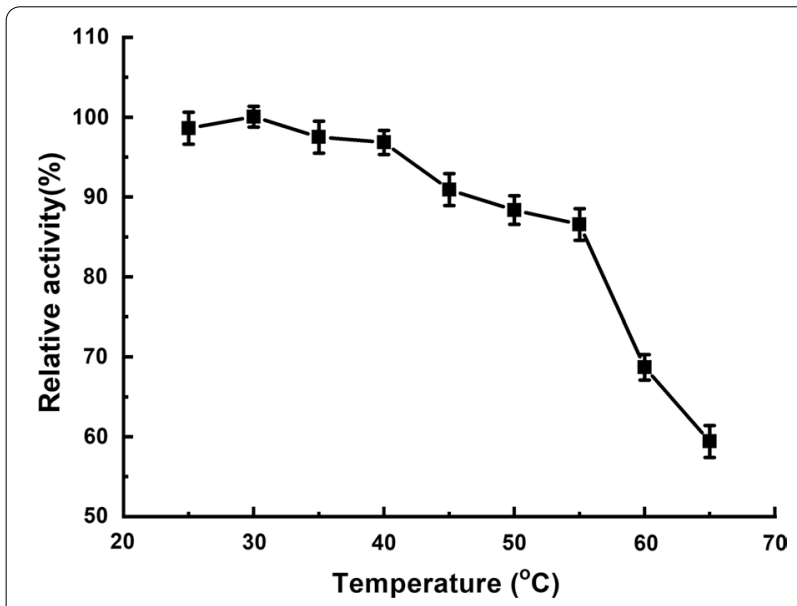

Fig. 5 Effect of temperature on activity of esterase Tan410

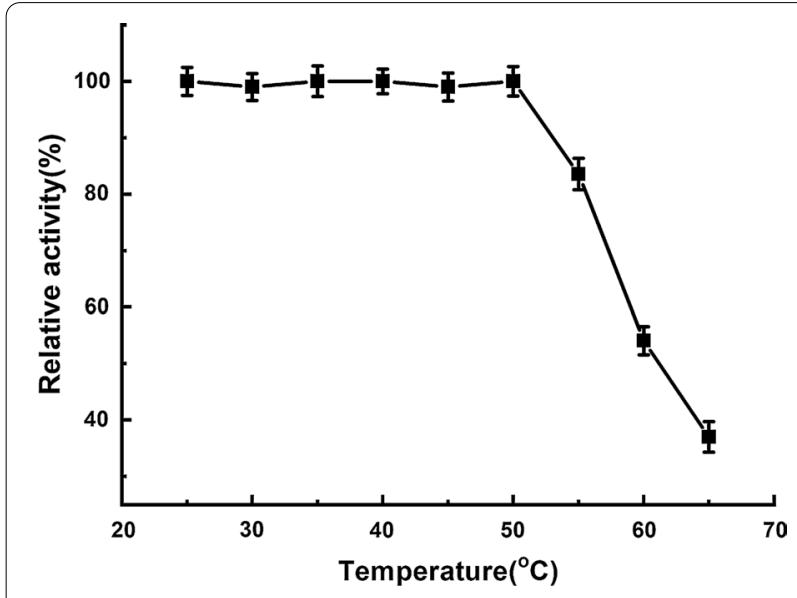

Fig. 6 Effect of temperature on the stability of esterase Tan 410
Table 1 Effects of different chemicals on esterase Tan410 activity

\begin{tabular}{|c|c|}
\hline Chemicals (5 mM) & $\begin{array}{l}\text { Relative } \\
\text { activity } \\
\text { (\%) }\end{array}$ \\
\hline Control & 100 \\
\hline $\mathrm{Mg}^{2+}$ & 83.2 \\
\hline $\mathrm{Mn}^{2+}$ & 67.6 \\
\hline $\mathrm{Cu}^{2+}$ & 79.5 \\
\hline $\mathrm{Co}^{2+}$ & 74.0 \\
\hline $\mathrm{Zn}^{2+}$ & 74.5 \\
\hline $\mathrm{K}^{+}$ & 87.4 \\
\hline $\mathrm{Fe}^{2+}$ & 56.1 \\
\hline $\mathrm{Ni}^{2+}$ & 64.7 \\
\hline $\mathrm{Ca}^{2+}$ & 80.3 \\
\hline $\mathrm{Ag}^{+}$ & 4.5 \\
\hline $\mathrm{Pb}^{2+}$ & 78.9 \\
\hline CTAB & 11.5 \\
\hline SDS & 0 \\
\hline PMSF & 84.7 \\
\hline \multicolumn{2}{|l|}{ Organic solvent (10\%) } \\
\hline $\mathrm{N}, \mathrm{N}$-dimethyl formamide & 105.6 \\
\hline Ethyl acetate & 94.7 \\
\hline Isopropyl alcohol & 98.5 \\
\hline Isobutyl alcohol & 89.0 \\
\hline Isoamyl alcohol & 37.4 \\
\hline Acetone & 95.7 \\
\hline Methanol & 100.1 \\
\hline Ethanol & 105.1 \\
\hline
\end{tabular}

gallate, propyl gallate, methyl benzoate, ethyl benzoate, vinyl benzoate, methyl 4-hydroxybenzoate, ethyl 4-hydroxybenzoate, methyl vanillate, methyl 2,4-dihydroxybenzoate, methyl 2,5-dihydroxybenzoate, methyl 3,4-dihydroxybenzoate, methyl 3,5-dihydroxybenzoate, methyl ferulate, methyl caffeate, methyl $p$-coumarate, methyl sinapinate and chlorogenic acid) could be hydrolyzed by the enzyme. Methyl ferulate was found to be hydrolyzed most effectively, while methyl sinapate could not be hydrolyzed by Tan 410 .

\section{Discussion}

Phenolic compounds, ubiquitous in plants were essential part of human diet, as they accounted for all most one-third of dietary phenols (Haminiuk et al. 2012; Esteban-Torres et al. 2015), which could be found in apple, artichoke, eggplant, grape, pear, potato and grape. They were also found in herbs such as eucommia, wormwood and honeysuckle (Santana-Gálvez et al. 2017). Phenolic compound had been reported to have anti-oxidant, anti-inflammatory, anticarcinogenic and antidiabetic 


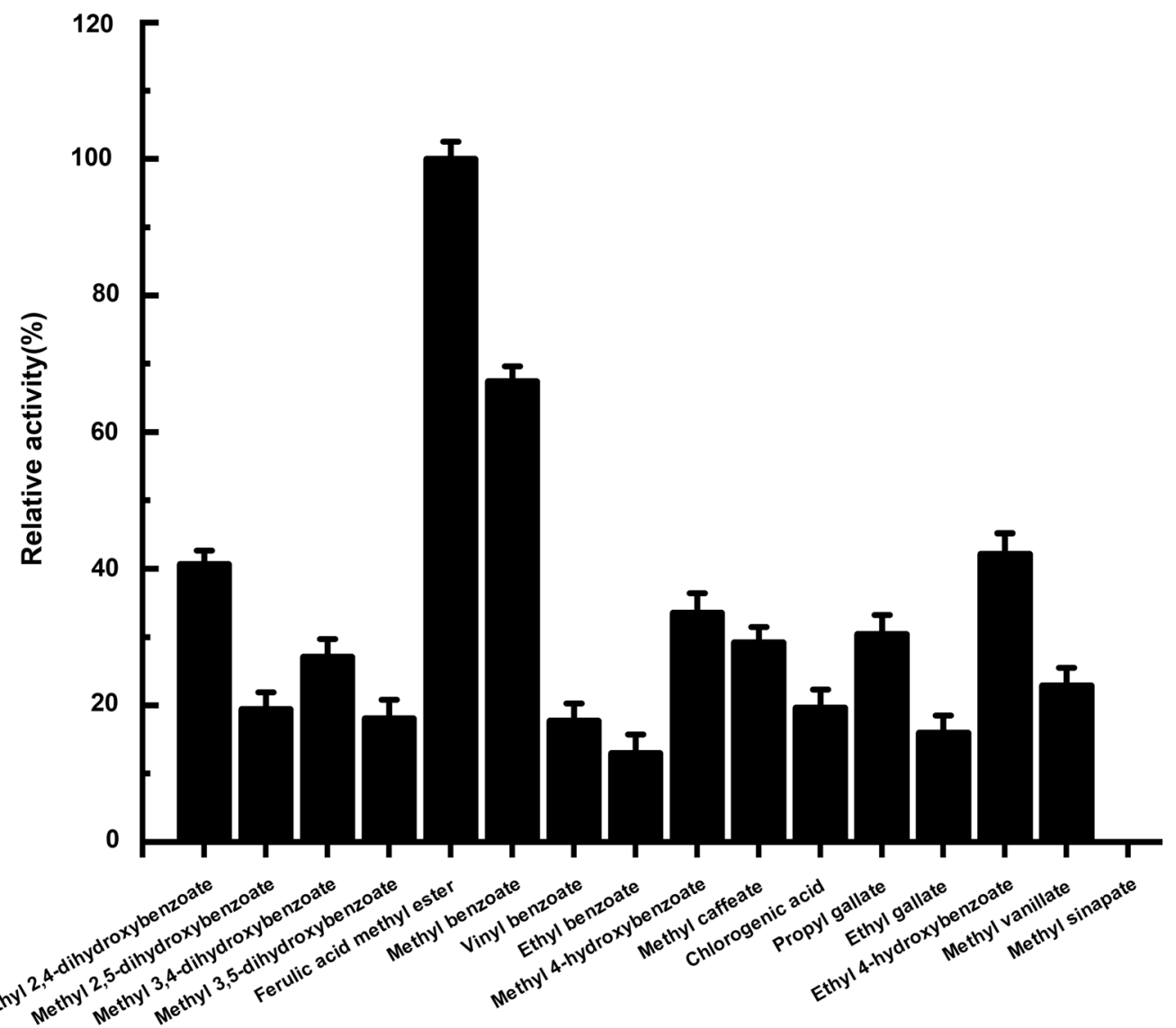

Fig. 7 HPLC analysis of different substrates hydrolyzed by esterase Tan410

activities. Therefore, enzymes which were able to release these compounds were not only essential for the degradation of plant but also of interest for the potential food and medical applications. In this study, a metagenomic library was constructed for screening esterase genes and a novel gene encoding multi-functional esterase was isolated. The gene (Tan410) encoding esterase was cloned and expressed in E.coli BL21(DE3) and the recombinant protein was purified for studying on enzymatic properties.

Substrates in a library were used for determining the substrate profile of Tan410. Based on activity observed, it could be concluded that Tan 410 showed a wide substrate range. Furthermore, it was interesting to find that Tan 410 could hydrolyze methyl ferulate, methyl $p$-coumarate and methyl caffeate, but not methyl sinapate, indicating that Tan410 showed feruloyl esterase activity and concluding that Tan410 was a type B feruloyl esterase. In addition, it was found that Tan 410 could also hydrolyzed chlorogenic acid and rosmarinic acid, which was in accordance with feruloyl esterase from Lactobacillus johnsonii (Lai et al. 2009). A few fungus feruloyl esterases, such as feruloyl esterase from Aspergillus niger (Levasseur et al. 2004), AoFaeB and AoFaeC from A. oryzae (Koseki et al. 2009), TsFaeC from Talaromyces stipitatus (Vafiadi et al. 2006), and Fae1A from Anaeromyces mucronatus (Qi et al. 2011) had been reported to show activity toward chlorogenic acid. However, their activities against rosmarinic acid were not analyzed. Furthermore, Tan 410 also exhibited activity against model hydroxybenzoic esters hydrolyzed by tannase (tannin acyl hydrolase), gallate and protocatechuate esters. Hydrolytic activity on esters from hydroxybenzoic acids was not a common activity on feruloyl esterases. To our knowledge, an enzyme Est_1092 possessing feruloyl esterase and tannase activity had been reported from from L. plantarum (Esteban-Torres et al. 2015). However, Est_1092 could not hydrolyzed chlorogenic acid and rosmarinic acid, while Tan 410 was able to hydrolyze chlorogenic acid and rosmarinic acid.

In early reports, it was found that tannase was limited to hydrolyze esters derived from gallic and protocatechuic acids. Iibuchi et al. had studied about the intermediate hydrolysates of tannic acid, substrate specificity, and inhibition of tannase activity by substrate analogues. 


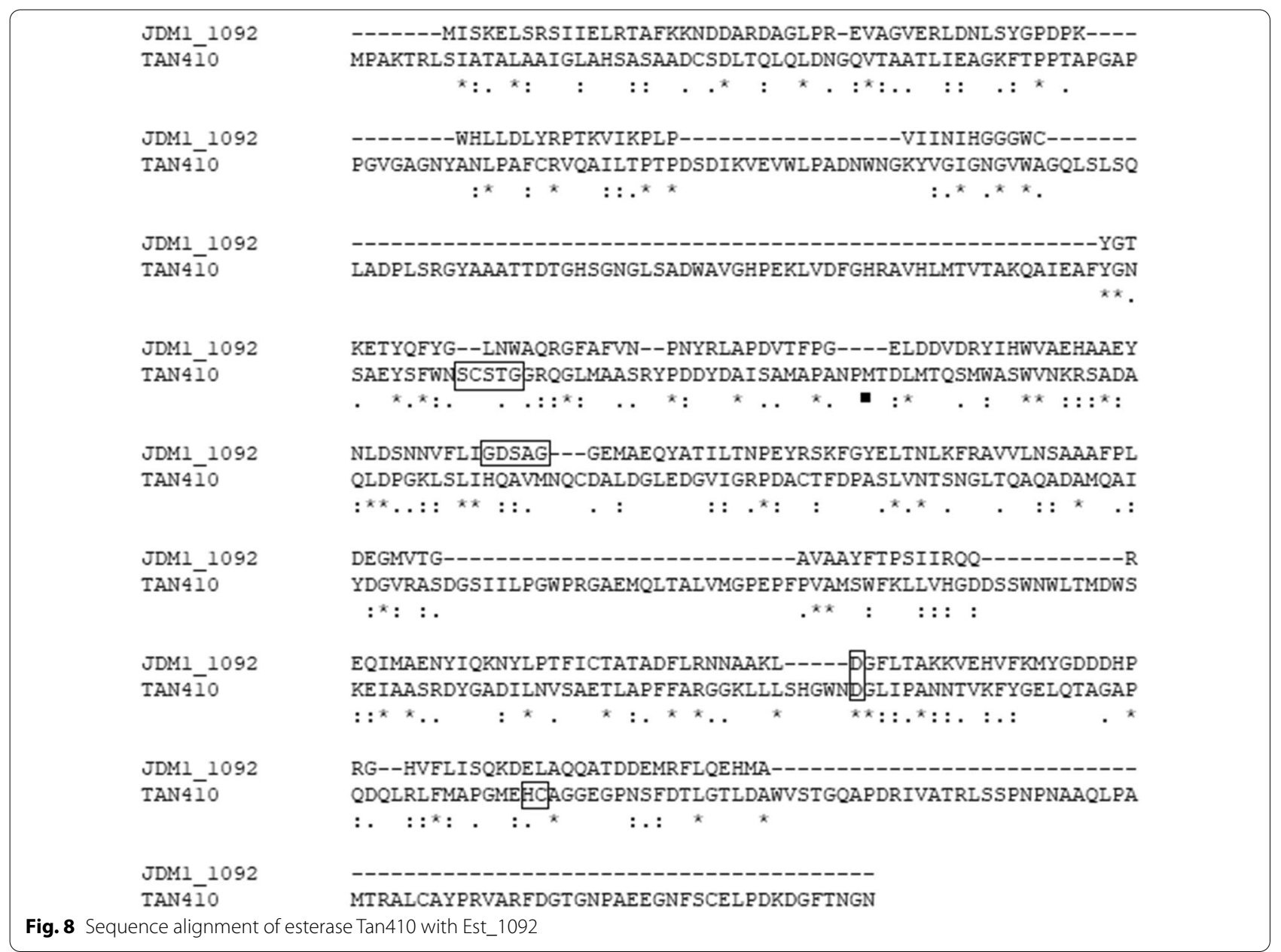

They found that only ester compounds of gallic acid could be hydrolyzed by tannase, except 3,4-dihydroxy methylbenzoate (methyl-protocatecuate) (Sadaaki et al. 1972). Ren et al. studied three-dimensional structure of a tannase from L. piantarum, and also studied catalytic and substrate binding sites. They found a catalytic triad (composed of Ser 163, His451, and Asp 419) in the structure and their mutagenesis studies revealed that residues in the catalytic triad and those interacting with three hydroxyl groups of the gallic acid were indispensable for the activity of tannase (Ren et al. 2013). The binding between hydroxyl groups of substrates and catalytic residues could be disrupted by mutation of catalytic triad residues, which caused the termination of catalytic reactions (Ren et al. 2013). Finally, they deduced that at least two of the three hydroxyl groups were needed to form a stable complex structure between the enzyme and a substrate (Ren et al. 2013). It seemed that tannase could not hydrolysis hydroxybenzoic acid without hydroxyl groups and hydroxybenzoic acid with substituents other than $-\mathrm{H}$ or $-\mathrm{OH}$ at position 2 (Esteban-Torres et al. 2015). However, in this study, it was interesting to find that Tan410 was able to hydrolyze benzoic esters (methyl benzoate, ethyl benzoate and vinyl benzoate) without hydroxyl group on the benzene group. Furthermore, it was also found that Tan410 could hydrolyze hydroxybenzoic esters (methyl 4-hydroxybenzoate and ethyl 4-hydroxybenzoate), dihydroxybenzoic esters (methyl 2,4-dihydroxybenzoate, methyl 2,5-dihydroxybenzoate, methyl 3,4-dihydroxybenzoate and methyl 3,5-dihydroxybenzoate) and vanillic ester (methyl vanillate). Therefore, Tan 410 was not only a feruloyl esterase and tannase because of its hydrolyzation of esters from hydroxycinnamic and hydroxybenzoic acids, but also was an esterase active on a broad range of esters from phenolic acids, which was similar to that of Est_1092 esterase from L. plantarum (Esteban-Torres et al. 2015).

As Tan410 was similar to Est_1092 in their enzymatic properties, the amino acid sequence of Tan 410 and Est_1092 was compared to see whether they showed higher similarity. Unfortunately, their amino acid sequence showed lower similarity (36.36\%). Amino acid 
sequence analysis revealed, that Est_1092 exhibited the conserved motif Gly-X-Ser-X-Gly typical of serine hydrolases which was converted to Ser-X-Ser-X-Gly in Tan410. Furthermore, structural motif CS-D-HC was found in Tan410 amino acid sequence, while it was not existed in Est_1092 amino acid sequence (Fig. 8). Maybe these features made Tan410 showed active on a broader range of esters from phenolic acids than that of Est_1092.

In conclusion, a gene encoding a multi-functional esterase Tan 410 was isolated from a metagenomic library. Tan410 showed highest activity toward $p$-nitrophenyl acetate, indicating it was a typical carboxylesterase rather than a lipase. Beside $p$-nitrophenyl esters, substrate profile revealed that the enzyme could also hydrolyze hydroxycinnamic and hydroxybenzoic esters, suggesting Tan410 was an enzyme active on a broad range of phenolic esters, which made it a valuable candidate for biological applications.

\section{Supplementary Information}

The online version contains supplementary material available at https://doi. org/10.1186/s13568-021-01198-5.

Additional file 1: Figure S1. Sequence alignment of esterase Tan410 with homologous sequences.

Additional file 2: Figure S2. SDS-PAGE analysis of recombinant Tan410. M, marker proteins, lane 1, purified Tan410.

\section{Acknowledgements}

We would like to thank Jiangxi Superrice Research and Development Center for providing the laboratory facilities for our biochemical analysis.

\section{Authors' contributions}

JY conceived and designed research. JY, LG and SCY performed the main experimental work. JY analyzed data, wrote and proofread the manuscript. All authors read and approved the final manuscript.

\section{Funding}

This study was funded by National Natural Science Foundation of China (31660016), Science and Technology Major Project of Science and Technology Department of Jiangxi Province (20182ABC28006).

\section{Availability of data and materials}

The datasets used and/or analyzed during the current study are available from the corresponding author on reasonable request.

\section{Declarations}

\section{Ethics approval and consent to participate}

Not applicable. The manuscript does not contain data collected from humans or animals.

\section{Consent to publish}

Not applicable. The manuscript does not contain any individual person's data.

\section{Competing interests}

The authors declare that they have no competing interests.

Received: 19 December 2020 Accepted: 23 February 2021

Published online: 05 March 2021

\section{References}

Castelluccio C, Bolwell GP, Gerrish C, Rice-Evans C (1996) Differential distribution of ferulic acid to the major plasma constituents in relation to its potential as an antioxidant. Biochem J 316:691-694

Cheynier V (2012) Phenolic compounds: from plants to foods. Phytochem Rev 11:153-177

Cosgrove DJ (2001) Wall structure and wall loosening. A look backwards and forwards. Plant Physiol 125:131-134

Crepin VF, Faulds CB, Connerton IF (2003) A non-modular type B feruloyl esterase from Neurospora crassa exhibits concentration-dependent substrate inhibition. Biochem J 370:417-427

Esteban-Torres M, Reverón I, Mancheño JM, Rivas B, de las, Muñoz R (2013) Characterization of a feruloyl esterase from Lactobacillus plantarum. Appl Environ Microb 17:5130-5136

Esteban-Torres M, Landete JM, Reverón I, Santamaría L, de las Rivas B, Muñoz R (2015) A Lactobacillus plantarum esterase active on a broad range of phenolic esters. Appl Environ Microb 81:3235-3242

Faulds CB, Williamson G (1995) Release of ferulic acid from wheat bran by a ferulic acid esterase (FAE-III) from Aspergillus niger. Appl Microbiol Biotechnol 43:1082-1087

Gao WY, Wu K, Chen LF, Fan HY, Zhao ZQ, Gao B, Wang HL, Wei DZ (2016) A novel esterase from a marine mud metagenomic library for biocatalytic synthesis of short-chain flavor esters. Microb Cell Fact 15:41

Gasteiger E, Hoogland C, Gattiker A, Duvaud S, Wilkins MR, Appel RD, Bairoch A (2005) Protein identification and analysis tools on the ExPASy server In: Walker JM (ed) The proteomics protocols handbook. Humana Press, Totowa, pp 571-607

Haminiuk CWI, Maciel GM, Plata-Oviedo MSV, Peralta RM (2012) Phenolic compounds in fruits-an overview. Int J Food Sci Technol 47:2013-2044

Hancock JM, Bishop MJ (2004) Dictionary of bioinformatics and computational biology. ORF Finder (Open Reading Frame Finder). Wiley, Hoboken

Inoue KH, Hagerman AE (1988) Determination of gallotannins with rhodanine. Anal Biochem 169:363-369

Ishii T (1997) Structure and function of feruloylated polysaccharides. Plant Sci 127:111-127

Jaleel CA, Riadh K, Gopi R, Manivannan P, Inès J, Al-Juburi H, Zhao CX, Shao HB, Panneerselvam R (2009) Antioxidant defense responses: physiological plasticity in higher plants under abiotic constraints. Acta Physiol Plant 31:427-436

Koseki T, Hori A, Seki S, Murayama T, Shiono Y (2009) Characterization of two distinct feruloyl esterases, AoFaeB and AoFaeC, from Aspergillus oryzae. Appl Microbiol Biotechnol 83:689-696

Koseki T, Mihara K, Murayama T, Shiono Y (2010) A novel Aspergillus oryzae esterase that hydrolyzes 4-hydroxybenzoic acid esters. FEBS Lett 584:4032-4036

Kosugi A, Murashima K, Doi RH (2001) Characterization of xylanolytic enzymes in Clostridium cellulovorans: expression of xylanase activity dependent on growth substrates. J Bacteriol 183(24):7037-7043

Kroon PA, Williamson G (1996) Release of ferulic acid from sugar-beet pulp by using arabinanase, arabinofuranosidase and an esterase from Aspergillus niger. Biotechnol Appl Biochem 23:263-267

Laemmli UK (1970) Cleavage of structural proteins during the assembly of the head of bacteriophage T4. Nature 227:680-685

Lai KL, Lorca GL, González CF (2009) Biochemical properties of two cinnamoyl esterases purified from a Lactobacillus johnsonii strain isolated from stool samples of diabetes-resistant rats. Appl Environ Microb 75:5018-5024

Larkin MA, Blackshields G, Brown NP, Chenna R, McGettigan PA, McWilliam H, Valentin F, Wallace IM, Wilm A, Lopez R, Thompson JD, Gibson TJ, Higgins DG (2007) Clustal W and Clustal X version 2.0. Bioinformatics 23:2947-2948

Levasseur A, Benoit I, Asther M, Asther M, Record E (2004) Homologous expression of the feruloyl esterase $B$ gene from Aspergillus niger and characterization of the recombinant enzyme. Protein Expres Purif 37:126-133

Natella F, Nardidi M, Di Felice M, Scaccini C (1999) Benzoic and cinnamic acid derivatives as antioxidants: structure-activity relation. J Agric Food Chem 47:1453-1459

Nieter A, Haase-Aschoff P, Kelle S, Linke D, Krings U, Popper L, Berger RG (2015) A chlorogenic acid esterase with a unique substrate specificity from Ustilago maydis. Appl Environ Microb 81:1679-1688 
Qi M, Wang P, Selinger LB, Yanke $\sqcup$, Forster RJ, McAllister TA (2011) Isolation and characterization of a ferulic acid esterase (Fae1A) from the rumen fungus Anaeromyces mucronatus. J Appl Microbiol 110:1341-1350

Ramírez L, Arrizon J, Sandoval G, Cardador A, Bello-Mendoza R, Lappe P, Mateos-Díaz JC (2008) A new microplate screening method for the simultaneous activity quantification of feruloyl esterases, tannases, and chlorogenate esterases. Appl Biochem Biotechnol 151:711-723

Ren B, Wu MB, Wang Q, Peng XH, Wen H, William JM, Chen QM (2013) Crystal structure of tannase from Lactobacillus plantarum. J Mol Bio 425(15):2737-2751

Rice-Evans CA, Miller NJ, Paganga G (1996) Structure antioxidant activity relationships of flavonoids and phenolic acids. Free Radical Biol Med 20:933-956

Sadaaki I, Yasuji M, Koichi Y (1972) Hydrolyzing pathway substrate specificity inhibition of tannin acyl hydrolase of Aspergillus oryzae No. 7. Agric Biol Chem 36:1553-1562

Santana-Gálvez J, Cisneros-Zevallos L, Jacobo-Velázquez DA (2017) Chlorogenic acid: recent advances on its dual role as a food additive and a nutraceutical against metabolic syndrome. Molecules 22:358
Silva FAM, Borges F, Guimaraĕs C, Lima JLFC, Matos C, Reis S (2000) Phenolic acids and derivatives: studies on the relationship among structure, radical scavenging activity, and physicochemical parameters. J Agric Food Chem 48:2122-2126

Tutuncu HE, Balci N, Tuter M, Karaguler NG (2019) Recombinant production and characterization of a novel esterase from a hypersaline lake, Acıöl, by metagenomic approach. Extremophiles 23:507-520

Vafiadi C, Topakas E, Christakopoulos P, Faulds CB (2006) The feruloyl esterase system of Talaromyces stipitatus: determining the hydrolytic and synthetic specificity of TsFaeC. J Biotechnol 125:210-221

Yao J, Fan XJ, Lu Y, Liu YH (2011) Isolation and characterization of a novel tannase from a metagenomic library. J Agric Food Chem 59:3812-3818

\section{Publisher's note}

Springer Nature remains neutral with regard to jurisdictional claims in published maps and institutional affiliations.

\section{Submit your manuscript to a SpringerOpen ${ }^{\circ}$ journal and benefit from:}

- Convenient online submission

- Rigorous peer review

- Open access: articles freely available online

- High visibility within the field

- Retaining the copyright to your article

Submit your next manuscript at $\boldsymbol{\nabla}$ springeropen.com 